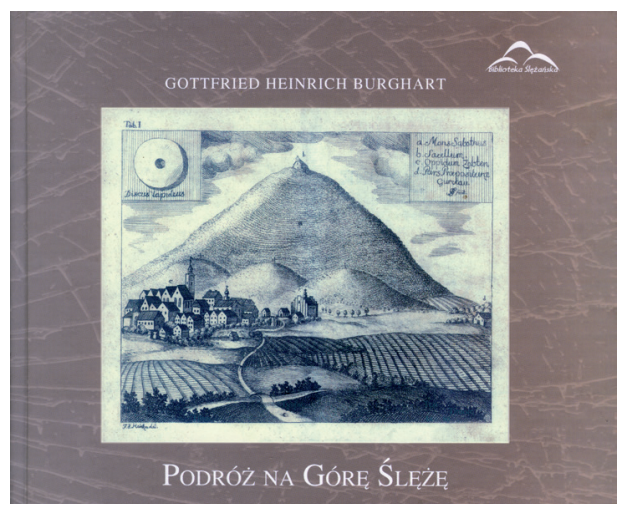

\title{
Książki o Sobotniej Górze
}

DOI: $10.19195 / 2084-4107.10 .25$

[rec.:] Biblioteka Ślężańska pod redakcją Wojciecha Kunickiego i Joanny Smereki (Wydawnictwo Atut):

Joanna Smereka, Kościót św. Jakuba w Sobótce, Wrocław 2007, ss. 240; Moritz Sadebeck, Góra Ślęża i jej okolice [Moritz Sadebeck, Der Zobtenberg und seine Umgebung, Breslau 1855], przełożyła Joanna Smereka, Wrocław 2008, ss. 113; Gottfried Heinrich Burghart, Podróż na Górę Ślęże, przekład i opracowanie Wojciech Kunicki, Wrocław 2012, ss. 252; Wojciech Kunicki, Od patriotyzmu do nacjonalizmu, Rok 1813 w Sobótce i jego rola w świadomości narodowej Niemców, Wrocław 2014, ss. 268; Ślężańskie Światy, pod red. Wojciecha Kunickiego i Joanny Smereki, Wrocław 2013, s. 460; Wojciech Kunicki, Natalia Żarska, Ślęża. Oświecenie, romantyzm, biedermaier. Sobótka i Góra Sobotnia (Zobtenberg) w opisach i dyskusjach od 1780 do 1860, wstęp, przypisy i opracowanie red. Natalia Żarska, Wojciech Kunicki, wyd. Muzeum Ślężańskie, Sobótka 2016, ss. 366; Seria Biblioteka Ślężańska pod red. Wojciecha Fabisiaka, Wojciecha Kunickiego i Marka Zybury.

\section{Books about Mount Sobótka}

Słowa-klucze: Góra, Sobótka, Ślęża, Dolny Śląsk, historia

Keywords: mount, Sobótka, Ślęża, Lower Silesia, history

„Na miasteczko Sobota spoglądając z bliska, / Widzimy górę tego samego nazwiska...” (B.Z. Stęczyński) — . ..do literatury i kultury polskiej owa góra weszła pod nazwą Soboty, Sobótki, Sobotniej Góry, ale po drugiej wojnie światowej ze względów motywowanych historycznie i z powodu pewnego rodzaju 
poprawności politycznej nazwana została Ślężą ${ }^{1}$ Podstawą tej nominacji było przekonanie, że pierwotna nazwa góry brzmiała „Ślęż” („Ślężec”!), co w dokumentach zapisywano w formach zlatynizowanych jako Mons Silentii ${ }^{2}$ (Zlenz, Zlenc), a (,prastara”!) nazwa ta wyparta została przez nową - Sobótka. Pisano o tym tyle razy, że nie trzeba się nad tym rozwodzić3 ${ }^{3}$, zauważając tylko, że tradycja tej nazwy została przerwana bodaj siedemset lat temu i jedyny wyraźny jej ślad ostał się w nazwie Śląska, co ustalił Jerzy Samuel Bandtkie, aczkolwiek nazwę Śląska wyprowadzał on od nazwy rzeki Ślęzy ${ }^{4}$, nie zaś od nazwy góry, co wynika z zapisu w kronice Thietmara: ,posita est autem haec in pago Silensi, vocabulo hoc a quodam monte nimis excelso et grandi olim sibi indito; et hic ob qualitatem omnibus nimis honorabatur" 5 . Do nieistniejącej, sztucznie rekonstruowanej tradycji ślężańskiej odwołano się na fali powojennych tendencji regermanizacyjno-integracyjnych ${ }^{6}$, dążąc do uniknięcia skojarzenia nazwy góry

${ }^{1}$ Do sprawy tej wypadnie w swoim czasie wrócić w oddzielnym artykule.

2 Absurd: „Mons Silenti” to „Góra Milczenia”, a nie Ślęża!

3 ,»Monte Silentii«, zamieniona w XIII w. na Sobótka od pobliskiej wsi Sobota, potem Sobótka [...] Sprowadzeni przez niego z Arrouaise we Flandrii mnisi (Kanonicy regularni reguły św. Augustyna, XII w.) zamieszkali pierwotnie „in monte Silentii alias Sobotka”, skąd z powodu wilgotnego klimatu panującego na górze przenieśli się do podnóża góry, do miejsca zwanego Gorca = Górka, niem. Gorkau”, Rospond, Zabytki języka polskiego na Śląsku, „Pamiętnik Instytutu Śląskiego" 15, seria 2, 1948, s. 17, s. 36. Kronika opatów klasztoru kanoników regularnych z Górki. Zob też: Słownik geografii turystycznej Sudetów, t. 20, Masyw Ślęży, Równina Świdnicka, Kotlina Dzierżoniowska, red. M. Staff, Wrocław 2005, s. 498; S. Rospond, Ślęża i je j derywaty, „Onomastica" 1955, nr 1, s. 7-40.

4 ,Znamy jednak ze średniowiecznych dokumentów pisanych również staropolską nazwę góry. Notowana jest ona do końca wieku XIII w formie: Zlenz, Slenz, Zlenc, Zlencz. Dopiero w XIV wieku ta prastara nazwa została wyparta przez nową, Sobótka, od osady, która u jej stóp się rozwinęła. Nazwa tej osady powstała prawdopodobnie w związku z odbywaniem w niej targów w soboty. [...] Rospond analizując średniowieczne materiały, w których nazwa góry kończy się na spółgłoskę, uważa jednak, że nazwa góry nie posiadała końcówki żeńskiej, lecz końcówkę męską, a więc brzmiała prawdopodobnie Ślężec, a nie Ślęża"; H. Cehak-Hołubowiczowa, Dlaczego Ślask od Ślęży?, „Rocznik Wrocławski”1, 1958, s. 23-25.

5 Kronika Thietmara, wyd. i przeł. M.Z. Jedlicki, Poznań 1953, s. 555 (1. VII, c. 59): „Owa góra doznawała wielkiej czci u wszystkich mieszkańców z powodu swego ogromu oraz przeznaczenia, jako że odprawiano na niej przeklęte pogańskie obrzędy”. Leszek Paweł Słupecki zwrócił uwagę, że Thietmar nie podaje nazwy góry wprost; pierwszy jej zapis pochodzi dopiero z XII w.; zob. L.P. Slupecki, Ślęża, Radunia, Wieżyca: miejsca kultu pogańskiego Słowian w średniowieczu, „Kwartalnik Historyczny” 99, 1992, nr 2, s. 3-15. Stanisław Rosik dał inną lekcję przekładu tego fragmentu: „leży ona [Niemcza] w kraju śląskim, któremu nazwę tę nadano od pewnej bardzo wyniosłej i wielkiej góry; a ta [w czasach], gdy tam otaczano czcią przeklęte pogaństwo, zażywała od wszystkich mieszkańców wielkiej czci z racji swych przymiotów i ogromu". W tej interpretacji góra była obiektem czci, a nie miejscem pogańskich praktyk; zob. S. Rosik, ,,Mons Silesia” (Ślęża) a kształtowanie się Śląska. Historyczny proces wobec najdawniejszej tradycji, [w:] Ślężańskie światy, red. W. Kunicki, J. Smereka, wyd. 2, Wrocław 2013, s. 67.

${ }^{6}$ M. Cetwiński, L.A. Tyszkiewicz, A. Lech, Prawda historii i racja stanu (mediewiści wrocławscy o średniowiecznym Śląsku. Pót wieku badań), „Sobótka” 2, 1992, s. 147-159.

Góry — Literatura — Kultura 10, 2016

(C) for this edition by CNS 
„Sobótka” z niemiecką formą „Zobtenberg”" Nie tak istotny jest dla niniejszych uwag fakt, iż motywy związane z expressis verbis tak nazwaną Sobótką, alias Sobotnią Górą, zajęły ciekawe miejsce w polskiej literaturze XIX w. (Roman Zmorski, Deotyma [Jadwiga Łuszczewska] Stefan Gębarski) ${ }^{8}$, natomiast znaczenie ma to, że pewni niemieccy autorzy w XVII i XVIII wieku operowali polską nazwą góry, podając ją m.in. w wersji „Sobotka”, „Sabotka” [!] ${ }^{9}$. Zwracam uwagę na te fakty, gdyż znakomitą edycję dzieła Gothofera Henryka Burgharta Iter Sabothicum w świetnym przekładzie na język polski tłumacz zatytułował Iter Sabothicum to jest szczegółowy opis kilku An. 1733 oraz w latach następnych Na Górę Ślężę [...] w oryginale zaś niemieckim występuje nazwa „Zobtenberg” (w zapisie „Zobten-Berg”) ${ }^{10}$. Użycie nazwy Góra Ślęża jest tu anachronizmem, który uzasadniać można tylko poprawnością administracyjną, historycznie bowiem logicznym przekładem nazwy „Zobtenberg” może być „Sobotnia Góra”, „Góra Sobota” (tak jak u Stęczyńskiego) i odnosi się to do całości dzieła. Sprawa operowania różnorakimi odpowiednikami niemieckiego dawnego nazewnictwa na Dolnym Śląsku jest z pewnością dość skomplikowana ${ }^{11}$. W praktyce translatorskiej dochodzi tu czasem do anachronizmów: niemiecki Riebenzahl stał się Liczyrzepą z inicjatywy Józefa Sykulskiego dopiero w 1945 r. jako autora książeczki Liczyrzepa, zły duch Karkonoszy (Jelenia Góra 1945) i to imię Ducha Gór stało się tak popularne, że dało nazwę popularnej grze liczbowej Liczyrzepka, a zatem podawanie imienia „Liczyrzepa” np. w omawianiu twórczości Johanna Karla Augusta Musäusa z 1783 r. byłoby całkowicie nieuzasadnione i mylące. Zarówno Sobóka, jak i wspomniany Rübezahl dobrze zakorzenili się na różnych poziomach w tradycjach kultury polskiej ${ }^{12}$ i żadna poprawność administracyjna tego nie zmieni, choć wspołcześnie góra nazywa się Ślężą. Nie budzi wątpliwości używanie w przekładach współczesnych nazw tam, gdzie są one pochodzenia słowiańskiego, miały zatem polskie brzmienie przed $1945 \mathrm{r}$. (typ: Domasław — niem. Domslau). W innych wypadkach rozsądek nakazuje podanie choćby dodatkowe w nawiasie obok nazwy tłumaczonej dosłownie -

7 Swoisty paradoks sytuacji polega na tym, że w Niemczech w okresie III Rzeszy były podejmowane próby zmiany nazwy „Zobtenberg” na „Silinberg” wspierane koncepcjami niemieckich historyków, którzy nazwę góry podawaną w zapisach średnowiecznych próbowali wyprowadzać od nazwy plemienia Silingów; zob. przypisy w niniejszej recenzji 2, 3, 4.

${ }^{8}$ Zob. np. M. Jonca, Rubecal i Sobótka - epizod w twórczości Stefana Gębarskiego, „Annales Silesiae” 23, 1993, s. 59-63; J. Kolbuszewski, Cztery romantyczne wizje Sobotniej Góry, „Annales Silesiae” 23, 1993, s. 37-58.

9 Podaje ich w rzetelnie opracowanej edycji Wojciech Kunicki; zob. np. G.H. Burghart, Podróż na Górę Ślężę[!],Wrocław 2012, s. 61, 121; Oświecenie, romantyzm, biedermaier. Sobótka i Góra Sobotnia (Zobtenberg) w opisach i dyskusjach od 1780 do 1860, Sobótka 2016, s. 15, 41, 107, 121 — godzi się jednak dodać, że tłumacze w tym tomie operują nazwą Góra Sobotnia.

10 G.H. Burghart, Podróż na Górę Ślężę. Edycja tekstu źródłowego przekład i oprac. W. Kunicki, Wrocław 2012.

${ }^{11}$ Abstrahuję tu od tego, że istnieją łatwo dostępne słowniki ekwiwalentów polskich niemieckiego nazewnictwa, bo nic to tutaj do rzeczy nie ma.

12 Zob. np. M. Jonca, op. cit. s. 59-63.

Góry — Literatura — Kultura 10, 2016

(C) for this edition by CNS 
nazwy dzisiejszej: tak postąpił Wojciech Kunicki w przekładzie Iter Sabothicum z nazwą góry Raduni, nazywając ją Sępią Górą z objaśnieniem w nawiasie, że Radunia, niem. Geiersberg (notabene jeszcze w 1949 r. była nazywana Sępią Górą). Podobnie postąpił tłumacz z słynną Łąką Sulistrowicką: u Burgharta występuje ona jako „Pfaffen Wiese”, co zgrabnie zekwiwalentyzowano jako „Kleszą Łąkę” z dodaniem w nawiasie owej nazwy dzisiejszej. Tak więc na pewno lepiej i rozsądniej by było, gdyby tytuł pracy Burgharta oddany został w przekładzie na język polski jako Podróż na Sobotnią Górę.

Sformułowane wyżej uwagi w niczym nie umniejszają naprawdę wielkiej wartości omawianej tu edycji dzieła Burgharta. W dziejach interesującej nas tematyki zajmuje ono pozycję wybitną, ma ogromną, wieloaspektową wartość poznawczą, a przy tym jest ciekawe i atrakcyjne nie tylko dla miłośników śląskiej góry, ale także dla szerokiego grona czytelników, interesujących się dziejami turystyki górskiej i tematyki górskiej w literaturze. Rzecz biorąc z literaturoznawczego punktu widzenia, trzeba zwrócić uwagę na perfekcyjność zaprezentowanego w niej warsztatu edytorskiego, a słowa uznania należą się też wydawnictwu Atut za znakomitą, piękną i funkcjonalną formę książki, w której symultanicznie zaprezentowane są reprodukcja pierwodruku i przekład dzieła. Wysokiej klasy jest też zaprezentowany w książce warsztat filologiczny. Wstęp Wojciecha Kunickiego zawiera ciekawą interpretację pracy Burgharta, erudycyjne komentarze i objaśnienia reprezentują też bardzo wysoki poziom, a dodawać nie trzeba, że wydanie polskiej wersji Iter Sabothicum było przedsięwzięciem naprawdę bardzo trudnym. Znacznie łatwiejsza do realizacji była edycja przekładu pierwszej prawdziwie naukowej monografii Sobotniej Góry, książki Moritza Sadebecka Góra Ślęża i jej okolice - Der Zobtenberg und seine Umgebung (1855), to zaś, że było to zadanie łatwiejsze, nie umniejsza ważności pracy Sadebecka i pozytywnej oceny jakości jej przekładu, niezależnie od faktu, że niemiecki badacz nie pisał o Ślęży, ale o Górze Sobótce. Uprzystępnienie książki Sadebecka jest o tyle ważne, że uprzytamnia jego rolę i miejsce w dziejach badań omawianej tu problematyki, a dla miłośników śląskiej góry jest to książka ciekawa.

Ważną pozycję w badaniach dotyczących miasta i regionu Sobótki należy przypisać także ciekawej monografii kościoła Świętego Jakuba napisanej przez Joanną Smerekę: interesująca zarówno pod względem merytorycznym, jak i metodologicznym książka dobrze wpisuje się w koncepcję studiów nad rolą miejsca i czynników organizujących wspólnotę lokalną. Podoba się i to, że autorka atrakcyjnie pisze o ładnym wnętrzu kościoła. Inny nieco charakter, acz także dotyczy w pewien sposób historii miejsca, ma studium Wojciecha Kunickiego Od patriotyzmu do nacjonalizmu, Rok 1813 w Sobótce i jego rola w świadomości narodowej Niemców. Autor przekonująco pokazał tu, jak element historii lokalnej (tworzenie Korpusu Ochotniczego Adolfa von Lützowa w Sobótce i Rogowie Sobóckim) nabrał znaczenia europejskiego. W historię zaś góry i turystyki górskiej interesująco wpisuje się relacja o studenckich komersach urządzanych w mieście i na górze.

$\mathrm{Z}$ kolei liczne studia z kilku dziedzin nauk przyrodniczych i humanistycznych zgromadzone w pokonferencyjnym tomie Ślężańskie światy są dowodem 
nieustannej atrakcyjności pewnych aspektów tematyki ślężańskiej i truizmem byłoby stwierdzenie, że mają istotną wartość naukową.

Osobną natomiast uwagę $\mathrm{w}$ krótkiej nocie zwrócić trzeba na szósty już tom w serii „Biblioteka Ślężańska”: Ślęża. Oświecenie, romantyzm, biedermaier. Sobótka i Góra Sobotnia (Zobtenberg) w opisach i dyskusjach od 1780 do 1860 - jest to wspólne dzieło Wojciecha Kunickiego i Natalii Żarskiej (2016). Abstrahując od dużej wartości dobrze napisanego wstępnego studium, któremu warto by poświęcić więcej uwagi, na co, niestety, nie ma miejsca, docenić trzeba szczególną wagę antologii, stanowiącej trzon książki. W szeregu autentycznie interesujących tekstów, które się w niej znalazły, odnaleźć można niezwykłe wręcz ciekawostki: informację o działalności nosicieli lektyk, którzy wygodnickich „turystów" wnosili na szczyt Sobótki, o napisach rytych na skałach (!) i drzewach, o pewnych pomysłach... grzebalnych, o próbach zrobienia z Sobótki Wezuwiusza przez zapalenie na jej szczycie ogromnego ogniska ${ }^{13}$. Pikantna jest prywatna relacja Josepha von Eichendorffa o jego noclegu w jednym łóżku z pewną atrakcyjną panną (kto ciekawy, niechaj zajrzy do książki). Myliłby się jednak ktoś, sądząc na podstawie tych słów, że zgromadzona w książce antologia jest tylko zbiorem anegdot. Zastanawiają np. możliwe do wykrycia filiacje wzmianek o skarbach na Sobótce ze spiskami tatrzańskich poszukiwaczy skarbów i może dają tu o sobie znać jakieś ich wspólne źródła walońskie, ale to trzeba zbadać. Poważnie zaś mówiąc: miarą rangi, jaką szeroko rozumiany krąg zagadnień dotyczących Sobotniej Góry uzyskał w literaturze niemieckiej schyłku XVIII i pierwszej połowy XIX w. jest fakt, iż w zgromadzonej w omawianym tomie antologii znalazły się teksty i utwory literackie autorów tej miary, co August von Kotzebue, Georg Gustav Fülleborn, Achim von Arnim, bracia Jacob i Wilhelm Grimm, Adelbert von Chamisso i Joseph von Eichendorff. Atrakcyjność jednak i poznawcza wartość prac zgromadzonych w tej antologii polega nie tylko na literackiej wartości wybranych utworów, ale także na poznawczym znaczeniu całości zbioru, dokumentującego przemiany w sposobie widzenia i opisywania krajobrazu dającego obraz przemian w sposobie postrzegania Góry i pisania o niej oraz jej obecności w folklorze śląskim. Wyraźniej tylko można było zaznaczyć, że baśń o wyprawie trzech snów po wodę życia dla umierającej matki odnotował na Mazowszu Roman Zmorski jako związaną z Sobótką, co ma znaczenie dla zrozumienia wielkości sławy tej góry i jej obecności nie tylko w kulturze niemieckiej, ale i polskiej:

Jak daleko sięgała sława Sobótki, jak cudowne między ludem krążyły o niej wyobrażenia, interesujące ślady zachowała nam po dziś dzień [1862] powieść gminna. Za chłopięcych jeszcze lat moich, kiedy o istnieniu szląskiej góry anim wiedział, będąc namiętnym opowiadań gminnych słuchaczem, po kilka razy w różnych okolicach Mazowsza, słyszałem baśń o jakiejś Sobotniej Górze, osobliwe opowiadającą dziwy,

13 W książce lojalnie wskazano, że pisał o tym w 1996 r. Wacław Sobociński; por. W. Sobociński, Ślęża jako Wezuwiusz. Plan wielkiego fajerwerku na szczycie Ślęży z 1801 roku na łamach śląskich czasopism, „Góry - Literatura - Kultura” 1, Wrocław 1996, s. 57-64.

Góry — Literatura — Kultura 10, 2016

(C) for this edition by CNS 
którą później z pamięci, najwierniej jednak tak co do treści, jak i do wszelkich znaczących szczegółów spisałem. Baśn ta nie tylko z powodu zawartego w niej o samej górze podania zajmująca, ale z całego swego ustroju i ducha do najstarożytniejszych i najpiękniejszych utworów należąca. więcej niż jakakolwiek inna zasługuje na upowszechnienie w czytającym świecie i dlatego w zupełności ją tutaj powtórzę ${ }^{14}$.

Mówiąc nawiasem, na ścianie obok wejścia do schroniska na szczycie Ślęży, wmurowana została w 1967 r. tablica ze słowami Romana Zmorskiego, które ponoć wpisał on w 1848 r. do „Księgi gości schroniska na Ślęży” [!]:

Na słowiańskiej góry szczycie,

Pod jasną nadziei gwiazdą,

Zapisuję wróżby słowa:

Wróci, wróci w stare gniazdo

Stare prawo, stara mowa - I natchnione Słowian życie.

Szkopuł w tym, że jak mantrę powtarzają ten fragment wszyscy niemal przewodnikopisarze i autorzy bardzo różnych tekstów o Ślęży, ale nie wiadomo, ani kto pierwszy znalazł ten wiersz, ani z jakiej księgi pochodzi ten cytat, ani też gdzie się ona znajduje. Być może napisano o tym w jakiejś publikacji, ale do naukowego obiegu ona nie weszła. Abstrahując od faktu, że trzeba tę zagadkową sprawę wyjaśnić i informację o owej jakiejś księdze ujawnić, można sugerować, że warto by ułożyć książeczkę złożoną z polskich utworów i prac o Sobótce i Ślęży (mogliby się do tego zabrać poloniści!). Inna rzecz, że spodziewać się można, iż w kolejce dzieł do wydania w „Bibliotece Ślężańskiej” znajdzie się Franciszka Fabera poemat Sabothus sive Silesia (Basilea 1592), bywa on bowiem nieraz cytowany w tych samych fragmentach, a publikacja jego całości ukazałaby i szerzej udostępniła ciekawy rozdział w historii śląskiej góry, wzbogacając bardzo ciekawą i wartościową serię wydawniczą. Nie ulega wątpliwości, że „Biblioteka Ślężańska" powstała dzięki inicjatywie, erudycji pracowitości i aktywności profesora Wojciecha Kunickiego, którego inicjatywę mądrze i dobrze wsparły Urząd Miasta i Gminy Sobótka oraz Muzeum Ślężańskie w Sobótce. Doceniając wartość dokonań profesora Kunickiego, który swej erudycji dowiódł także „pozaślężańskimi” pracami (np. godna polecenia świetna edycja średniowiecznego poematu Ksiązę Ernest [2013]), słowa uznania wyrazić też trzeba pod adresem wspomnianego Urzędu i Muzeum, bo także dzięki nim miasto Sobótkę widać wyraźnie na kulturalnej mapie Polski.

Jacek Kolbuszewski

14 R. Zmorski, Sobótka. Góra na Śląsku, „Tygodnik Ilustrowany” 1862, nr 119, s. 7. Zob. też: Sobotnia Góra. Podanie, [w:] R. Zamarski, Podania i baśni ludu w Mazowszu (z dodatkiem kilku śląskich $i$ wielkopolskich), spisał Roman Zamarski [!], Wrocław 1852; J. Krzyżanowski, Romana Zmorskiego „Sobotnia Góra”, [w:] idem, Paralele. Studia porównawcze z pogranicza literatury i folkloru, Warszawa 1961. 